\title{
Gendering Memory: Intersectional Aspects of the Polish Politics of Memory
}

\author{
Inga B. Kuźma \\ University of Łódź, Institute of Ethnology and Anthropology of Culture
}

\section{Edyta Pietrzak}

Łódź University of Technology

Institute of Social Sciences and Management of Technologies

DOI: http://dx.doi.org/10.18778/1733-8069.16.1.07

\section{Keywords:}

emancipation of memory, herstory, historical politics, private sphere, public sphere, alternative memories

\begin{abstract}
The article is devoted to the process of gendering memory as a counterpoint to the politicization of memory observed in the Polish context. The core problem of the paper is a description of a local case of this type of gender 'memory practising' in the area of the public urban sphere, specifically one created by the Łódź Women's Heritage Trail Foundation (https://www.facebook.com/ŁódźkiSzlakKobiet) - a gender-profiled female grass-roots initiative that is concerned with the city's past.
\end{abstract}

The article consists of three main parts referring to, respectively, the functioning of memory in the urban public sphere as a form of dialogue (hemerneutic-interpretative anthropology with Jurgen Habermas' and Seyla Benhabib's theories is the theoretical foundation here), the process of gendering memory (appearing alongside the narrative phrase and feminist proposals for the interpretation of memory as a form of its pluralization), and the presentation of the activities within the Łódź Women's HeritageTrail Foundation's particular initiative - namely 'Women Routes in Łódź' - as a kind of case study for the city as a landscape of memory.

The paper deals with the tension observed between the politics of memory and the political practice, and the alternative memories that arise from the idea of multiplicity and polyphony, including the voice of women. The authors raise the issue of the genderization of memory in the context of an inquiry into how the pluralism of collective memory and the diversification of the public sphere develops as a result of the discourses and operation of the alternative memory, including gender-focused memory.
Inga B. Kuźma, Associate Professor at the Institute of Ethnology and Anthropology of Culture (IEiAK), University of Łódź - the director of IEiAK and also the head of the Centre of Social Innovations at the University of Łódź; a member of SIEF and a board member of F.E.R Eurethno. Her research interests include: social exclusion and inclusion, empowerment of excluded groups, engaged and public anthropology, anthropological methodology, her- story. She is an expert in FEANTSA in the Housing Rights Cluster.

\section{Contact details:}

University of Łódź

Institute of Ethnology and Anthropology of Culture 90-131 Łódź, ul. Lindleya 3/5 email address: inga.kuzma@uni.lodz.pl 
Edyta Pietrzak, Associate Professor of Social Sciences in the discipline of Political Science. She works in the Institute of Social Sciences and Management of Technologies at the Lodz University of Technology. She is the author of numerous scientific publications, the editor-in-chief of the 'Civitas Hominibus' yearbook, and an expert in EU social projects. Her major academic interests include theories of citizenship, margins and

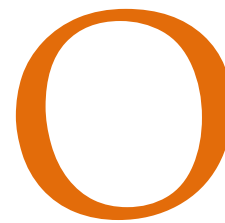

ur research interests and educational projects ('Women War and Peace,' realized under Europe for Citizens, http://smashingtimes.ie/theatreandfilmcompany/women-war-and-peace/; and 'Connecting Memories,' realized within the program of Erasmus+ KA2 Strategic Partnership 2017-2019 Project number: 2017-1-DE02-KA204-004260, http:// comem.weltgewandt-ev.de $L$ ) focus on pluralistic gender memory and its functioning in the context of the radicalization of memory. We are interested in how the gendering of memory corresponds to the radicalization of political life as it is experienced in Poland, as well as how the pluralism of Polish collective memory and the diversification of the public sphere have been shaped through the discourses and actions of alternative memory.

Since history is a closed structure, it can be assumed that memory is open to individuals and collectives, and thus susceptible to various activities that they extract from it, giving it various contexts at the same time. These individuals and groups seek a justification by "inventing" the past and memory (cf. Hobsbawm and Ranger 1983) not only for themselves, but also for larger communities to which they refer (it can be a nation, a state, or another kind of community, including ethnic ones) peripheries of the public sphere, and the politics of diversity.

\section{Contact details:}

Łódź University of Technology

Institute of Social Sciences and Management of Technologies 90-924 Łódź, ul. Wólczańska 215

email address: edyta.pietrzak@p.lodz.pl

which is important because of the value system that unites its supporters. The process of "inventing" is common for all micro, meso, or even meta memories, and so also for groups so far considered as those suppressing their voice (Muted Groups Theory, cf. Ardener 2005:50-54), such as women's discourses and herstorical practices, which is what this paper addresses.

Collective memories reconstruct rather than record the past due to various goals pursued by the group, including those resulting from conflicts of memory. These conflicts reveal dividing lines among interpretations and assessments of the past that exist within various social groups, countries, as well as in the international context. They expose myths and stereotypes, but also gaps and deformations in thinking about the past and ideologies that have been confronted (Forecki 2014:193-194). This type of tension is related to the competitiveness of memory (not only of the past, because it also translates into the present), rivalry between different images co-existing within the group, and the distinction between the 'familiar' and the 'other.' Competitive stories are rejected or reinterpreted to serve the community's purpose, which is preserving the community and stability, i.e., staying within the frames, supporting the effort of self-identification. 
It should be mentioned that - according to Michel Foucault - counter-narratives refer to bottom-up historiographies of excluded minorities or marginalized groups. Therefore, alternative images of the past and subversive epistemologies of remembering (Gajewska 2012:13-30) are, first of all, a reaction to the selectivity and principality towards the past and memory that characterizes mainstream, and, secondly and collaterally, they are also a sign of the pluralization of memory that manifests in the form of various micro-narratives (cf. Korzeniewski 2010 as cited in Lipiński 2015). These are also created by various types of minority movements and, hence, by female groups as well. These circles in Poland, most often associated with non-governmental organizations (human rights, developmental, awareness-raising, and education) and academic centers. They are characterized by the insider's approach, i.e. the majority of created stories or herstories and meta-discourses, or polemics with the mainstream, are created by people who are personally involved in the description of their own worlds ${ }^{1}$.

The situation in Poland provides cases for analysis regarding the trends prevailing in a wider context. This specific research area, as well as the direction of interpretation, has been determined by the fact that, first, the intersectional and gender perspectives are treated as minor issues in the Polish research of the politics of memory; second, the gender category itself is not part of the mainstream paradigms occurring in the Polish public discourse; third, Poland is an interesting example of a country undergoing a transition within just one generation (the last thirty one years since the year 1989), i.e. it has

\footnotetext{
${ }^{1}$ See some Polish achievements of this kind, including selected academic publications, textbooks, catalogs of artistic exhibitions, and non-formal education texts, such as: Abramowicz, Biedroń, and Kochanowski 2010; Penn 2014; Niziołek 2016a, 2016b; Kowalczyk 2018; Majewska 2018.
}

moved from the system of the centrally-controlled socialist state to the democratic one. Although this transformation cannot be perceived as evolutionary or progressive, during the process of change the Polish people had to face antithetic messages, competitive visions of the past, present, and future, as well as their own myths. These are the grounds for our thesis herein, namely that a change like the one observed in Poland is not one of the processes that progress evenly as a stable transgression to the new reality. On the contrary, it entails adding new elements to the existing cultural core, which changes the existing perspective.

The authors of this article gravitate towards an approach based on the hermeneutic method of Hans Georg Gadamer (Gadamer 1993). Hermeneutics is an attempt at understanding Others. Our study refers to the situation of an inquirer. An inquiry presupposes a situation of a conversation, i.e. a dialogue that leads to cognition. This dialogue concerns the relationship between the past and the present, the old and the new, the tradition and the change. There is an understanding generated in the process of these two time horizons meeting. The same occurs when ideological and mental perspectives meet and confront. This method influenced the interpretative approach in social sciences, including the development of interpretative anthropology, and inspirations from Paul Ricoeur's theories (Ricoeur 1973; 1976; 1984). The most distinct representative of the interpretative school in anthropology is Clifford Geertz (1983; 2005).

Anthropological interpretation is a construction of examining what is happening, what specific people do, speak, and think. Cutting off this kind of interpretation from what is happening, and thus from its locality, makes it an empty composition (Geertz 
2005:33). Locality takes on a special sense in the situation of the most basic feature of the modern world that various theories, including the interpretative ones, had to confront, namely the phenomenon of progressive diversion. The disintegration of large, coherent systems into weakly connected smaller structures makes it difficult to demonstrate the relationship of local realities with superordinate entities. Thus, if there is a task for a theory, it opens here. One has to create new, general concepts or modify the old ones in order to be able to penetrate the chaos of heterogeneity and say something useful about its forms and future (Geertz 2005: 274-275). We need ways of thinking that are perceptive to details and individual cases, to singularities, discontinuities, contrasts, and unique things, i.e. what Charles Taylor calls "deep diversity" (Taylor 1993:155-186). By extension, this approach cannot ignore the question of self-determination that the modern concept of agency entails. It was discussed from a feminist perspective by, among others, Bronwyn Davies (1991). As Angela Kristin Vandenbroek (2011:482) states when discussing that analysis,

[...] Davies argued that individuals must recognize the ways they are constituted through discourses and then act as authors to disrupt, contradict, and rewrite the discourses that constitute them. [...] However, she was quick to point out that [...] it is impossible for an individual to escape the discourses that constitute the self. An individual can only recognize the multiplicity of discourses involved in the constitution of the self and resist, subvert, and induce change within those discourses. Thus, agency, in this framework, is the ability to author and have a voice within the discourses one is involved in.

The hermeneutic structure which we have developed during our research is not only based on the classical model of the spiral of understanding (hermeneutic-interpretative circle), but it also passes through a few levels. Among them, we have distinguished the level where the individual backgrounds and experiences in the form of cultural expressions enter the public sphere and, at the same time, co-shape a wider, i.e. social, circulation of knowledge, consciousness, and the system of values, namely public discourses (cf. Wodak and Keller 2008; Herzog 2016).

We intend to focus on a description of a local case of dislocation of the public sphere, created by the Łódź Women's Heritage Trail Foundation ${ }^{2}$ (https://www. facebook.com/ŁódźkiSzlakKobiet).

We also employ Seyla Benhabib's ideas, in particular her interpretation of the Theory of Communicative Action and the Theory of the Public Sphere, both developed by Jürgen Habermas. In our opinion, the research carried out in this way - i.e. that it goes through the three above-mentioned levels - enables us to describe the dynamics and changes taking place in the public sphere, where there are diverse discourses of memory and ways of translating it into political practice, and thus into the sphere of political use.

\section{Memories Emerging from the Shadow: Herstory as the Diversification of the Public Sphere}

According to Seyla Benhabib, the critical Theory of Communicative Action by Jürgen Habermas may play a significant role in the emancipation postulates, including the emancipation of memory ${ }^{3}$ and gender-

\footnotetext{
${ }^{2}$ More information about the organization and initiative can be found at: https://www.facebook.com/ŁódźkiSzlakKobiet.

${ }^{3}$ The policy of emancipation means an attitude towards the liberation of individuals and groups from social restrictions
} 
ing memory. Its advantage is that it relativizes the stiff nature of the division into the private and the public, and offers the possibility of reformulating this division after its oppressive character is proven. This is exactly what the feminist movements have shown - in the public-private division they have identified the foundation of the discourse of domination that justifies the female oppression and exploitation in the private sphere (Benhabib 2005:87). On the other hand, Habermas' discursive model that defines the public sphere comes from the egalitarian norm of reciprocity and designs the democratization of social norms, including those concerning family and gender (Frazer 1987: 31-56).

Here, Hannah Ardent's concept with regard to the public space seen in the context of appearing (Arendt 2000) is also worth mentioning. It is used by researchers of intercultural relations in a way which is similar to our approach herein (see: Göle 2016). It emphasizes the fact that the desire to reveal oneself, to speak up, to show oneself, and, therefore, to leave the shadow is important. This is what our metaphor about pluralistic memories refers to - speaking up and appearing in the public space in a distinctive way (Göle 2016:69). By dint of such gestures ${ }^{4}$ it is becoming more and more common, i.e. shared. The more 'Other People' fill this gap and become visi-

that negatively affect one's life opportunities and the abolition of asymmetrical social relations, as well as the differences between, e.g., the ruling and the ruled, rich and poor nations, contemporary and future generations, women and men, the white and the non-white, the supervised and the supervising, the infantile and the mature, and other artificial divisions like these.

${ }^{4}$ Thus, it is a case of social behaviorism, i.e. the issues related to who (and how) appears in the public space and how they act in it. In other words, the individual enters such space with a selected type and repertoire of motoric and oral actions - as well as other actions performed with specific artefacts - and, hence, transforms a particular topography and triggers a specific reaction. ble, the more it has a chance to become commonly shared, i.e. with all people granted the same rights.

The above-mentioned Habermas' model - which places the discourse before the division into the private and the public occurs - implies a transformation of both these areas. When a parliamentary democracy is appropriated by commercial media under pressure and business groups, there is no space for addressing women's issues in the public discourse, the resolution of which depends on the decisions made by the authorities that appropriate questions raised by feminists, animal rights defenders, or sexual minorities. Ipso facto, the authorities claim the right to decide about these issues. This is why, according to Benhabib, feminists should enter into the dialectical covenant with the Habermas theory (Benhabib 2005:87). A lack of space for publishing socially important issues introduced by feminism and the need for legal regulations both mean that solutions proposed by feminists are convergent with the liberal perspective (e.g., Rosemarie Tong) or the moral authoritarianism, which is a reversal of the patriarchal attitudes (e.g., Catharine MacKinnon and Bethke Elshtain).

Therefore, the case of the Łódź Women's HeritageTrail seems truly compelling to us, just like other similar initiatives in Poland; in 2014, some of them formed a coalition under the "Herstory Network" name. Their objective is to disseminate issues proposed by feminists through activities with the use of a particular space (the city), literally understood as a physical and symbolic construct.

According to Habermas, at the level of the pluralistic public sphere, communication processes take the form of spontaneous "communication streams" that cannot be fully organized. Together with the 
lifeworld, these areas of the public sphere create spontaneous articulations of problems that appear in the social space, which (if they have the appropriate weight and reach) gain the rank of political problems and become part of the organized public discourses aimed at solving them.

This is why Habermas' public sphere has two faces. The first one - the "anarchist" - is connected to the lifeworld, in which the public discourse undergoes distortions due to, for example, pressure form the political power, economic conditions, media, or inequalities. This discourse is rich in diversity and open to transformations. Only on its basis can organized forms of the public discourse take shape and this is the second face of the public sphere, i.e. one that regulates procedural issues using rational explanations and interpretations of law. This side of the public sphere is close to the Habermas' ideal communication model. However, this other type of the public sphere does not live its own life, because it is based on the already mentioned "anarchic" face of the discourse, in which the public opinion is shaped in an informal way (Habermas 2005:337).

\section{Feminist Approaches to the Politics of Memory and Gendering Memory}

The concept of gendering memory belongs to the same category as the concepts of body gendering, care gendering, etc. Therefore, it entails a kind of analysis of social phenomena that are treated as constructions based on the cultural and social dimensions of gender. The gender of memory is one of the points of view of the analysis of the contemporary memory policy, understood as official, leading, bottom-up, alternative, inherent, and specific narrative that is associated with various social movements, minorities or, among others, women's movements, which are not homogeneous. According to the theoreticians of gendering memory (i.e.; Hirsch and Smith 2002; Leydesdorff, Passerini, and Thompson 2009;), "[C]ultural memory [its part constitutes also the gendering memory - E. P., I. B. K.] is located in a specific context rather than subsumed into monolithic and essentialist categories" [Leydesdorff 2009:viii].

Gendering memory enters into a dialogue with postfeminism, as well as, earlier, with both the second and the third wave of feminism in the West. In the case of the second wave, it was about a key concept, which was female or women's experience. The thirdwave theorists, however, recognized in the notion of female experience "a suspicious concept," which was based on critical voices coming from two sides, namely from poststructuralism that acknowledged both the experience and subjectivity as discursive effects, and from postcolonial theory, which pointed out that this notion introduced differences between women and functioned as a hegemonic norm (Sieracka 2015:76-77). The problem of experience returned with postfeminism, but it was privatized and underwent extensive individualization; people turned away from the old "private is political" slogan. This is linked to concepts constituting Western neoliberal democracy. Moreover, the former feminist language of liberation from oppression and the rejection of the role of victims by women ceased to be compatible with the experience of those women who did identify with the values of this political and economic system. These women, who denied the 'rhetoric of victimization', did not want to articulate the experience of oppression, treating this type of discourse as an attempt to relinquish responsibility for their own helplessness, laziness, and bad choices, and blame it on external factors. Being a victim was identified by them as a culpable personal fail- 
ure. It is also connected with the neoliberal imperative of success, which in the postfeminist discourse takes the form of slogans such as "girl power" or "you go, girl" (Sieracka 2015:79). These gestures of rejecting the perception of women as victims also occur alongside the contemporary return to the idea of difference and being different, which is claimed to be a source of individual strength as well as pleasure. The current popularity of gendered female experience shows that the rejection of this concept during the third wave could have been too hasty, because, as consequence, one of the most important existential experiences of women has been forgotten. It has, however, come back and revealed women's need to experience, among others, their own corporeality, physicality, and presence. A woman, according to postfeminism, is not an object of observation or someone else's action, but an agent of the system, an active subject, because she is in possession of a variety of tactics - from defending to affirming such a situation for her own purpose. Still, women's experience of one's own corporeality is lined with ambiguity. The female body - the main element of difference and the key of experience - may sometimes become an excuse for exclusion. Here, another ambiguity of contemporary feminism opens. It takes the form of gendering memory that comprises of giving a gender context to memory, past, and herstory. It happens through corporeality that is dressed in a specific discourse. Women's history is history of both the triumphant body and the used body. At this point, it is easy to fall into a trap. The "used" part entails 'without the consent of the woman' and 'without her conscious participation.' In fact, from a herstoric point of view, contemporary readings of history marked by trauma (e.g. wars, extermination, genocide) often show a lack of heroism within these events, because they have been described as a corporal experience of women (as participants and witnesses). It is also the experience of using women's bodies by the women themselves in order to fight or survive, saving themselves or someone else. The following texts are worth analyzing this way: Bartuś 2014; Waxman 2017; Kuciel-Frydryszak 2018; Madejska 2018; Ostrowska 2018, Urbanik-Kopeć 2018. Does a woman's consent to give her own body for the use of others - to surrender and sacrifice it for survival or another purpose - indicate her passivity, or does it make a subversive agent out of her? Due to the specific cultural hyperbolization of the value attributed to female corporality, women's experience of the body may be related to the perception of it as a value contained in high contexts and Great Narratives, i.e. one that is incompatible with everyday experiences. Where, then, does the female body as a cultural phenomenon end, and the experience of her own individual body begin? And how does this ambivalence relate to the sense of identity? All these considerations do not mean that we as the authors of this paper relativize the suffering and trauma of women affected by tragedies. Rather, we wish to point to all interpretative ambiguities and what consequences could arise from, first, introducing stories about once physically present women into the public sphere - which also manifests physically in the urban tissue, monuments, buildings, streets, etc. - and, second, presenting them in the form of maps.

\section{Gendering of Memory as a Counterpoint to the Politicization of Memory}

In the Polish politics of memory ${ }^{5}$, we have been dealing with two important memory turns. The

\footnotetext{
${ }^{5}$ Historical politics, or politics of memory, is nothing more than shaping the historical consciousness and provoking a public discourse on the memory of the past. These concepts are derived from Germany, where they were created after the reunification of the country in 1989 (Saryusz-Wolska 2009). In Polish,
} 
first one is based on the radicalization of memory, while the second one on introducing alternative memories - memories 'emerging from the shadow.' The turn of the 1990s and the 2000s, which was the time when new countries joined the European Union (Poland did so in 2004) was important for the latter trend. Those were specific milestones for shaping a different memory and changing the approach to remembering. Memories that emerge from the shadow also refer to diversity understood in a broad sense. ${ }^{6}$

the former term has much worse connotations than the latter one. Namely, historical politics means that the state funds scientific research and institutions dealing with the memory, and supports educational activities in this area by organizing public holidays, defining attitudes and values, as well as labeling the heroes or using polyphony in the narrative in order to gain some benefits related to the development of national identity (Wawrzyński 2014). In Poland, historical politics is an issue which triggers stormy debates and is often perceived as an element used to manipulate the public opinion and shed a particular light on history in a way that suits the ruling political elites. The politics of memory, on the other hand, is a less politically charged term; the focus here is placed on the collective memory rather than on its politicization. Nonetheless, both terms are very often used interchangeably. They also refer to the concept of collective memory (Halbwachs 2008), which is associated with the identity of individuals and communities. In this light, the past in our memory is adapted to our identity and results from the ethnic origin, social class, or power relationship. However, in addition to the relationship of the collective memory and identity, the relationship between politics of memory and the authorities is also vital. It is like this due to the fact that collective memory refers to the legitimization of the existence of a given community, its structures, and forms of the political power. Time management and the attitude of the community to time is the source of power and, at the same time, the way in which the power is exercised. It is the political power that determines what and how should be remembered (Szacka 2006). Therefore, the issue of women's commemoration and raising the topic of their participation in history has a political meaning.

${ }^{6}$ In traditional socio-political organizations, manifestations of diversity such as age, sex, ethnic origin, religious faith, physical agility, social status, or sexual orientation functioned either on the margins of the public sphere or only in the private sphere, repeatedly giving rise to exclusion. Currently, we are observing a global process of shifting the position of the representatives of diversity from the periphery of the political scene to its center, and the growing strength of the voices of the hitherto marginalized minorities. See: Parekh 2000; Naser and Honneth 2003; Kymlicka2007; Putnam 2007.
The first turn has launched the values identified with the 'far right' movements and strengthening the national identification - which consists in politicizing - and, thus, it has given a political character to memory ${ }^{7}$.There are also gender-related threads in this trend, but more in the context of maintaining the patriarchal understanding of gender roles. A radical breach from the pluralistic discourse of memory led to the political and cultural breakthrough in 1989 that consisted in strengthening the identity of the group seeking national identification. In this case, the desired social model (reflected - but at the same time strengthened and justified - by memory) was a monolithic and static system based on a classical cultural mechanism built upon the binary system of opposing values, spaces, and communities. It manifested in the most evident way by the opposition "orbis exterior - orbis interior" (the 'I/not-I' model, the 'we/they' kind of thinking). This system emerges from some kind of social consciousness, which can be compared to the isolationism of consciousness described by Ludwik Stomma (Stomma 2002). In the theory of politics, this opposition is also described by, among others, Carl Schmidt (2000) and developed by Chantal Mouffe (2008) in the context of the opposition between friends and enemies. For that reason, the radicalization of memory in Poland depends on its politicization - there is an ad hoc social game with the memory in its center; the game reflects the already existing social divisions, but also deepens and fosters them. The "orbis exterior - orbis interior" opposition is repeated at each level of the social structure. According to this thought,

\footnotetext{
${ }^{7}$ Politization is a multi-faceted process of adding a political character to the phenomena that were not political originally, e.g. spiritual culture or artistic creativity. Consequently, it is an influence of politics on the functioning of the administration, media, and the everyday and private life, which manifests in the tendency for politics to permeate all areas of life, subordinating social phenomena and transformations to the rules of the politics (Karwat 2010:64,70).
} 
the gender-related threads appear in the context of maintaining the patriarchal understanding of gender roles, in which females are passive and males are active. Presenting a participation of a woman in public events consists in emphasizing her responsibility for supportive and protective roles, as well as organizational measures. The leadership or conceptual participation of women is either not noticed, or not interpreted as such. Moreover, what is characteristic for such a type of activity, i.e. the second plan action, is providing procurement and care. A characteristic feature of the politics of memory shaped independently by nationalist movements is the emphasis on women's patriotism, manifesting in the process of raising subsequent generations of patriots, the support given to fighting men, or holding public functions.

The radical version of the politics of memory (usually used as a tool of national-state propaganda) departs from the pluralistic discourse of memory that has been present in Poland for the thirty one years of the socio-political transformation. The project of radicalization of memory focuses on consolidating the community around values attributed to the nation, which usually also means closing it to everything that is considered foreign. It is also related to a patriotic attitude centered around the homeland, i.e. a common territory treated as the material core of identity. Radicalizing memory sharpens the image of the world and creates a black-and-white landscape in which a nation (typically, the term 'people' is not used in this context) 'get up from their knees' and find, e.g., the dignity and pride taken away from them as a result of changes (according to trauma-based discourses). The transformation that was synonymous with change was oriented towards polyphony, where the previously ignored and not taken into account discourses were now debated, often contrary to the lead- ing Great Narrative and, hence, belonging to minorities in the broad sense, as well as to the excluded or to "muted groups" (Allport 1954).

It is this kind of memory, or rather memories, that emerge from the shadows that create the second recollection of memory. It is an alternative memory, defined by contestants as "bad memory" (Kwaśniewska and Niziołek 2014; Saryusz-Wolska and Traba 2014:396-403) or counter-memory. It is devoid of greatness. When, for example, the actions of Poles during World War II were recognized not only as noble and sacrificial, but also defiled by evil and a lack of solidarity or humanitarianism (predominantly against the Jewish population), or when the entire European system changed, Germany - Poland's 'long-time enemy' (also in accordance with the narrative of the Polish People's Republic) - became an ally and mentor. Since the 1990s, the research trend for memories that revised the mythological heroic history has become stronger. Given the current political situation in Poland 8 , the Polish-government-controlled media and opinion centers treat this tendency as awkward and harmful, because it can spoil the good memory and advantages of the country. The reason for this approach is that this trend contradicts the re-mythologization of memory that is a consequence of - and also a driving force behind - its radicalization. The recent radicalization is not really anything new, but, rather, constitutes an enhanced response to explicit pluralism of memory that is 'polyphonic' on many levels, including gender.

The manifestation of the pluralism of memory was fostered by political changes that were caused by

\footnotetext{
${ }^{8}$ The governance of the Law and Justice (Prawo $i$ Sprawiedliwość), a right-wing conservative party.
} 
the entry into a new political and economic system after the fall of socialism, i.e. the escape from the oppressive discourse of the then authorities. However, the beginning of this polyphony can be traced to 1970, when the opposition to the political system in Poland began to grow. New underground sources of information were created and, thus, new interpretations of the present and the past emerged. Polyphonic memory also includes local history that came about after the overthrow of socialism.

\section{The City as a Remembrance Landscape Related to the Radicalization and Feminization of Memory}

One example of the described process of diversification of the public sphere is herstory, which creates a new quality of culture and civic history. This can be attributed to an invented tradition (Hobsbawm and Terence 2008), i.e. one that is lived, experienced, depicted, and embodied. An invented tradition is a set of rules and practices that stem from them that are adopted silently or explicitly; its purpose is to instil other values and norms by repeating certain behaviors, practices, and gestures. Therefore, herstoric practices are not lacking the element of performativity and commitment; they are not limited to the sphere of postulates or theories. The main goal of the aforementioned Trail initiative is to build the city's memory from elements other than those that produce colloquial and official knowledge about it.

It is also about emphasizing formal associations using a different angle in order to include them in the dialogue and, finally, deconstruct them and read the past in accordance with the 'female key.' In Łódź, this practice engages in a dialogue with stereotyp- ical images of the city, such as "a city of women," "a city of many cultures,"10 or "a city without history/tradition," and, finally, "a city difficult to live in." These selected features of the city, treated as essential elements of its identity (perceived through objects, circumstances, and places), evoke specific attitudes among the inhabitants. They are also components of tradition. This tradition, however, is not impersonal and, therefore, it should be treated as suitable for people. This approach is supported by the understanding that people have traditions and they have the right to have them.

Trips and walks proposed by the Trail are very popular forms of learning about, and experiencing, the indigenous population (von Rohrscheidt 2011:143). These forms - especially those developed at a grassroots level by animators - introduce the memory of everyday lives of people, ordinality of life, and non-heroism, which is usually associated with the existence of women. Fleeting everyday life, usually enclosed in individual memory, must be present and inscribed in a particular space and discourse so that it can be perceived, identified, memorized, and

\footnotetext{
${ }^{9}$ As part of the Women's Heritage Trail, the history of Łódź contains many elements related to factories and workplaces, where the most important problems of everyday life of a large number of city residents once occurred. These factories were the place of the initial (though partial) emancipation of women. Urban identity had its origins in the $19^{\text {th }}$ century and was the result of many Łódź inhabitants' participation in unions and political actions, including street demonstrations, education, cultural life, etc. Life in the city gave an opportunity to interfuse and mix lifestyles represented by different groups of women. This is why the Trail gives voice back to the folk class. ${ }^{10}$ Łódź was established in the $15^{\text {th }}$ century. Just before the First World War, the small agricultural town transformed into a textile industry center. Immigrants from Silesia, Czechoslovakia, Moravia, Brandenburg, but also Switzerland, France, and England flowed to the city. The city became a "promised land" (as it was easy to get rich here) and a place of coexistence of many cultures and religions - a place of the permeation of influences as well as a cultural and ethnic borderland. The multicultural atmosphere in Łódź prevailed until the outbreak of World War II.
} 
so that it can supplement the previous memory and be applied in space, thus inscribing a different way of perceiving that space and being in it. This alternative herstory should be shown, i.e. created, or new ways which would allow others to feel it should be looked for. It would have to be added to the public discourse, which, in consequence, would generate a real diversity within it. In order to achieve this, one needs real faces, names, and memories, i.e. real heroines and events. This is why the Łódź Women's Heritage Trail is primarily focused on creating individual and collective portraits (e.g. textile women) against the background of the city in order to reveal places where specific events and everyday life of some women took place.

Walking can, under certain circumstances, become a strategy of resistance for the weak against the stronger (de Certeau 2008), which can be understood as an expression of rebellion and subversion. This is one of the purposes of walks and lectures about the city, which take place as part of the Łódź Women's Heritage Trail; during their course, the aforementioned deconstruction of the perception of the city and women takes place (Szlaki kobiet. Przewodniczka po Polsce emancypantek 2015:53-67). The herstoric trail proves that due to a large population of women in the city (predominantly working women), social problems - as well as women's and human rights have gained additional value and entered the sphere of great politics. This manifested through demonstrations of workers on the streets of Łódź during the 1905 Revolution, or strikes of the Łódź industry sector in the 1970s and 1980s (Szlaki kobiet. Przewodniczka po Polsce emancypantek 2015:58-60), including the Hunger March that took place in Łódź on July 30, 1981. The postulates raised at that time showed what should be understood by the "private is political" slogan: the women, mainly working women, most often pointed to supply problems and insufficient infrastructure, the improvement of which was necessary to perform caring functions. These are, of course, social spheres that are culturally attributed to women. They also raised the issues of wages, working conditions, and sexual abuse.

When visitors to Łódź go to the Women's Heritage Trail, a new process of gendering the city - as well as its history and the memory of it - occurs. In other words, the city's re-establishment takes place (Pink 2011:139). The foregoing perception changes, just like the context and understanding of what was happening in the city, who lived in it, what they did, and who they were. Recalling the stories of Łódź's women and the events in which they took part i inevitably accompanied by issues related to ethnicity, religion, economics, as well as the political ones, linked with education, reproduction, care functions, age, and others. It is something unavoidable whenever the topic of women, including women from Łódź, is raised ${ }^{11}$, because Łódź has been a multicultural and multi-religious city from the very beginning of its existence.

Women have always had a certain "spatial capital" (Erbel 2010:73) as well as, it should be added, a memory capital that corresponds to female representations in space, history, and in memory, which are elements also responsible for the expression of women themselves. However, the use of only alternative discourses against the dominant one seems insufficient in order to carry out a significant subversion and to exist in space and memory in one's own right. A physically transformed space is a pre-

\footnotetext{
${ }^{11}$ In a sense, this is a reference made by the creators of the Trail to the postulates of the third wave of feminism, which emphasized social class, ethnicity, religious beliefs, etc., which -alongside gender -are indicative of diversity between individuals. Focusing solely on gender and not including the other categories does not provide a sufficient explanation.
} 
requisite of achieving it. Therefore, one needs to create a new (real) space for themselves or annex an existing one in order to use it in one's own way.

When bearing in mind the thesis of de Certeau that says that walking can become a sign of rebellion, disagreement, and a reversal of order, following the Women's Heritage Trail becomes more than just an experience of a different story about the city. It be- had previously been marginalized or treated as so obvious that they seemed transparent and were ignored (e.g. women and their daily activities) are now re-discovered. The subversive practice of the Women's Heritage Trail is reinforced by a city map, which is distributed to the walkers or during meetings. ${ }^{12}$

\section{Photo 1. Map prepared by the Łódź Women's Heritage Trail.} comes an act of taking possession of the public space. Who is the guide and talks about the women? In the case of the Łódź Trail of Women's Heritage, these are women who do it from the perspective of their own experiences, or draw on the experiences of other female eyewitnesses of the past. This way, the presented stories are based on herstorical sources and personal memories of the inhabitants of Łódź. An application of new symbols to the hitherto recognized images - and describing the past and space with the help of other stories and voices changes the place and the discourses which are present in it into the areas of a new, different meaning. However, it is not only about introducing women where they were not (sufficiently) represented, or even about providing them with a stronger capital of space and memory. A more important goal is to inscribe their everyday life into the history and space of the city, rooting them, together with their its colloquiality, in the present.

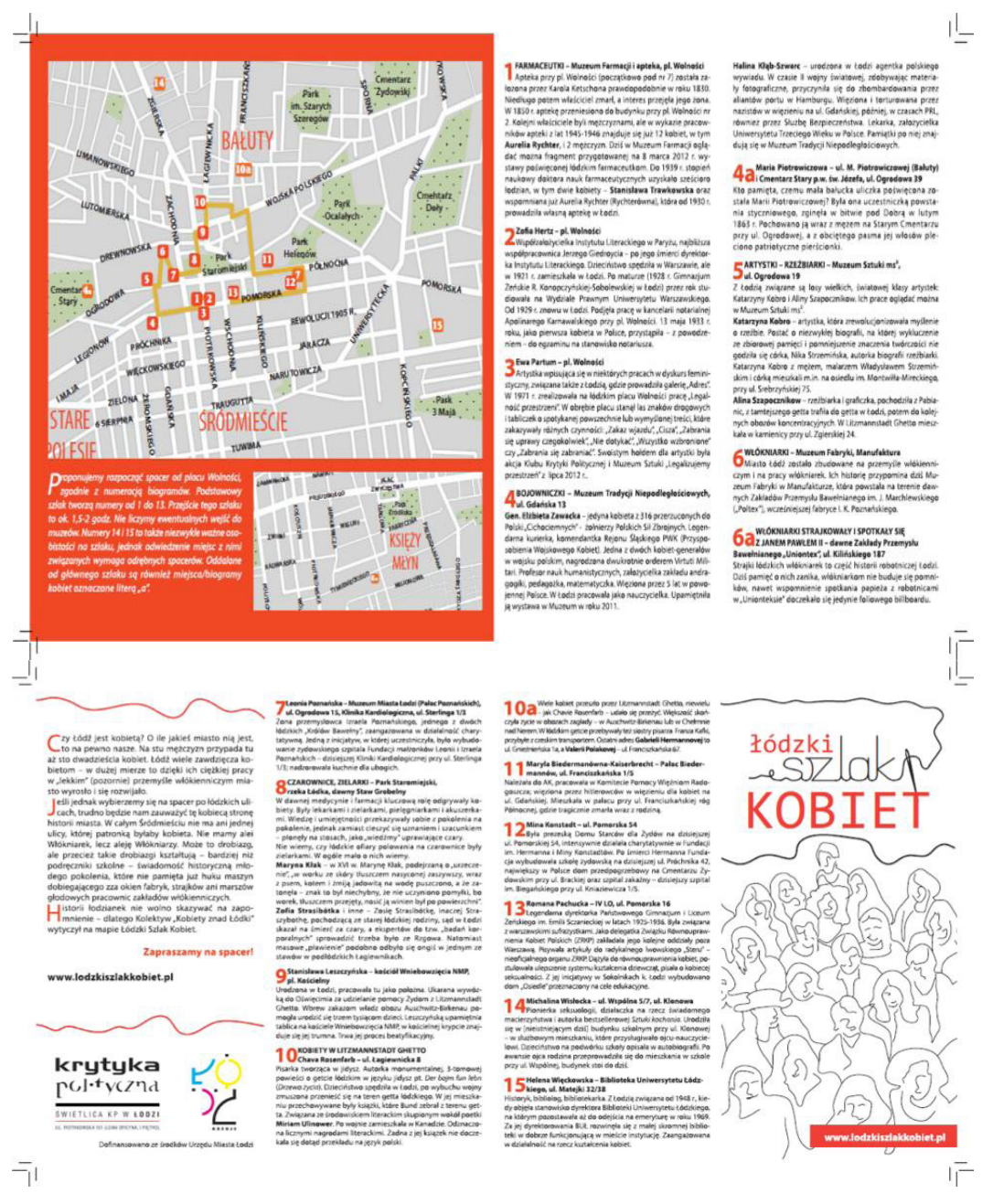

\footnotetext{
${ }^{12}$ An example of the first and main herstorical trail and the map of Łódź city center, prepared by the Foundation of Łódź Women's Heritage Trail (available only in Polish).

The presented map is the first of the created walking maps on women's routes for the needs of guided tours (it was created in 2012, the presented graphic shape was obtained thanks to funds obtained in 2013). They are also routes for independent sightseeing of the city (thanks to the attached descriptions), prepared by activists of the Łódź Women's Trail Foundation. This route is called classic - centered around the very center of the city and tells about women from different eras.
} 
Despite the eclecticism of this first women's trail in Łódź, which primarily stems from different times in which its heroines lived and acted as well as the diversity of their professions, the criteria for selecting women are about many features that they had in common. Among them, there is, on the one hand, independence and decision-making - including financial and professional independence (wives of manufacturers, a librarian, pharmacists, textile workers, women engaged in resistance, a midwife) - and, on the other, creativity and ingenuity (artists from various fields of art) and the involvement in, among others, matters important for women, from education to health (a suffragist, a school headmaster, and artists). Finally, some of the heroines represented typical "muted groups," such as physical workers (textile workers), women without formal knowledge and power (the alleged witches - women who most often came from rural underclass and had indigenous knowledge), or artists belonging to ethnic and religious minority groups, including language minority groups (e.g. Yiddish writers and poets).

The process of situating the heroines in a specific space of the city, i.e. in its central part, results from the fact that in these places the majority of the women worked or lived (except for two places; the first one was selected, because it is a point dedicated to witches and herbalists, while the second one - the Museum of Pharmacy - commemorates the pharmacists symbolically). Despite the fact that many of these women were commemorated with plaques or by naming public spaces or public buildings after them (e.g. a hall in the University Library, a city square, a square in a shopping center-initiatives that are independent of the creators of the Trail), only composing a story about both women and Łódź brings out new contents from under the mainstream and official layer of memory. It is worth emphasizing that the women's trail passes in the immediate vicinity of the symbols of the Great Narrative set, e.g. by monuments (of the national hero Tadeusz Kościuszko at Plac Wolności, or of Moses with the ten commandments plate in the Staromiejski Park), along the buildings indicating power, e.g. past the town hall or church (also at Plac Wolności), through the current economic authority (Manufaktura), and at the former political prison (now the Museum of Independence Traditions [Muzeum Tradycji Niepodległościowych]). At this last spot, there are no memorial plaques or information about female prisoners; there is a plate that commemorates former prisoners as a whole and another one that is specifically dedicated to Józef Piłsudski - the leader of Poland regaining independence in 1918 - who was imprisoned here for two months in the year 1900. Therefore, the herstoric layer remains in a dialogue with the Great Memory and events with heroic features.

On maps, places related to women's stories are marked with points that show their connections with specific spots. Those women lived at different times and differed in social background, religious beliefs, views, and activities. However, the apparent lack of convergence between the heroines is not as important as the freedom to create one's own routes and the act of seeking similarities and differences between particular women. Moreover, the above-mentioned temporal and thematic eclecticism creates a network of new connections, and also reflects the structure of memory or its palimpsest character in a more realistic way. Map users decide what is interconnected and what meanings they will take out of the city. The herstorical map provides them with the key, but not ready solutions. This type of reading undermines the perception of 
history and memory as objective and static structures. On the contrary, it enables creation based on traditional formal concepts, which reveals new contexts (Vuković 2007).

The Łódź Women's Heritage Trail, like other initiatives of this type, is an alternative to local history and memory habits. It problematizes the space, perception, and discourses about the past in points where they seem neutral and familiar. Cultural and social heterogeneity is manifested through these types of activities, because the herstoric memories "drawn from the shadows" reveal alternative contents and perpetuate them in the human perception.

\section{Concluding Remarks}

The aim of this paper was to outline the dynamics of transformations taking place in the public sphere, in which various discourses of memory - as well as possible ways of translating it into the political practice - appear. The authors gravitate towards an approach based on the Hans Georg Gadamers' hermeneutic method, which is an attempt to comprehend Others. In the process of meeting two ideological and mental horizons and their confrontation, an understanding is created. The hermeneutic structure which we develop during our research is based on the classical model of the hermeneutic circle and it goes through the following stages:

- sub-interpretation as an area of the individual background and a person's experience of the world, including remembering and forgetting; in other words - how a given individual gains and shapes their own understanding of what they encounter by living within a specific culture;
- the public sphere as an area of experience and shaping social elements - the circulation of knowledge, consciousness, and the system of values, i.e. public discourses, where the focus is on the description of the local case of dislocation of the public sphere, created by the Łódź Women's HeritageTrail;

- meta-practices, i.e. the manner in which these public discourses are transformed intopolitical practice, building monuments, museums, or naming streets. Here, we draw from the ideas of Seyla Benhabib, in particular from her interpretation of the Theory of Communicative Action and the Theory of the Public Sphere by Jürgen Habermas.

The conducted research allowed us to describe the dynamics and changes taking place in the public sphere, in which various discourses of memory appear, as well as various ways of translating it into political practice, and thus into the sphere of political use. The authors intended to show this at the level of the public sphere, where individual backgrounds and experiences are transformed into cultural (i.e. normative) expressions that construct the social circulation of knowledge, awareness, the system of values, and public discourses.

We believe that studying the situation of the formation of cultural expressions perceived as public discourses (see the described Trail of Women's Heritage in Łódź) is helpful in determining the dynamics and changes taking place in the public sphere, where, as already mentioned, there are various memory discourses and where the paths of their translation into political practice, and thus their political use, are contradictory. 
The process of argumentation is made in three main areas corresponding to the main parts of this paper. The first one was about outlining the functioning of memory in the Polish public sphere while referring to the radicalization and politicization of memory observed in the recent years, based on the theories of the public sphere of Habermas

\section{References}

Abramowicz, Marta, Biedroń, Robert and Kochanowski, Jacek (eds). 2010. Queer Studies. Podręcznik kursu [Queer Studies. Course Manual]. Warsaw: Kampania Przeciw Homofobii.

Allport, Gordon W. 1954. The nature of prejudice. Cambridge: Addison-Wesley Publishing Company.

Ardener, Shirley. 2005. "Ardener's Muted Groups: The genesis of an idea and its praxis." Women $\mathcal{E}$ Language 28(2):50-54.

Arendt, Hannah. 2000. Kondycja ludzka. Warsaw: Wydawnictwo Aletheia.

Bartuś, Alicja (ed.). 2014. Kobiety wojny. Między zbrodnia a krzykiem o godność. Auschwitz: Fundacja na Rzecz MDSM w Oświęcimiu, Państwowe Muzeum Auschwitz-Birkenau.

Benhabib, Seyla. 2005. “Trzy modele sfery publicznej.” Krytyka polityczna 3:87.

Davies, Bronwyn. 1991. "The concept of agency: A feminist poststructuralist analysis." Social Analysis 30:42-53.

de Certeau, Michel. 2008. Wynaleźć codzienność. Cracow: Wydawnictwo Uniwersytetu Jagiellońskiego.

Erbel, Joanna. 2010. “Gender w mieście. Jak perspektywa urbanistyczna zmienia myślenie o płci?" Pp. 61-82 in Krakowski Szlak Kobiet. Przewodniczka po Krakowie emancypantek. Vol. 2, edited by E. Furgał. Cracow: Fundacja Przestrzeń Kobiet.

Forecki, Piotr. 2014. “Konflikt pamięci." Pp. 193-195 in Modi memorandi. Leksykon kultury pamięci, edited by M. Saryusz-Wolska and R. Traba. Warsaw: Wydawnictwo Naukowe Scholar. and Benhabib. The second one was about showing the tendency to gender memory within the Polish context. The third part was a detailed reference to the alternative narrative of creating a gender-based memory policy, which is addressed through action (the Łódź Women's Heritage Trail) as gendering memory in the urban landscape.

Frazer, Nancy. 1987. “What's Critical about Critical Theory? The Case of Habermas and Gender." Pp. 113-143 in Feminism as Critique, edited by S. Benhabib and D. Cornell. Minneapolis: University of Minnesota Press.

Gadamer, Hans-Georg. 1993. Prawda i metoda. Zarys hermeneutyki filozoficznej. Cracow: Inter Esse.

Gajewska, Agnieszka. 2012. “Wywrotowość.” Pp. 13-30 in Teorie wywrotowe. Antologia przekładów, edited by A. Gajewska. Poznan: Wydawnictwo Poznańskie.

Geertz, Clifford. 1983. Local knowledge: Further essays in interpretive anthropology. New York: Basic Books.

Geertz, Clifford. 2005. “Opis gęsty. W poszukiwaniu interpretatywnej teorii kultury." Pp. 17-47 in Interpretacja kultur. Wybrane eseje, edited by C. Geertz. Cracow: Wydawnictwo Uniwersytetu Jagiellońskiego.

Göle, Nilüfer. 2016. Muzutmanie w europie. Dzisiejsze kontrowersje wokót islamu. Cracow: Wydawnictwo Karakter.

Habermas, Jürgen. 2005. Faktyczność i obowiazywanie. Warsaw: Wydawnictwo Naukowe Scholar.

Halbwachs, Maurice. 2008. Społeczne ramy pamięci, Warszaw: PWN.

Herzog, Benno. 2016. “Discourse analysis as immanent critique: Possibilities and limits of normative critique in empirical discourse studies." Discourse E Society 27(3):278-292.

Hirsch, Marianne and Valerie Smith. 2002. "Feminism and Cultural Memory: An Introduction." Journal of Women in Culture and Society 28(1):1-19. 
Hobsbawm, Eric and Terence Ranger (eds.). 1983. The Invention of Tradition. Cambridge. New York, New Rochelle, Melbourne: Cambridge University Press.

Jabłońska, Natalia. 2009. "Polityka przechadzki. Konstruowanie i doświadczanie przestrzeni miejskiej warszawskiej Pragi." Konteksty. Polska Sztuka Ludowa 1-2:226-235.

Karwat, Mirosław. 2010. "Polityczność i upolitycznienie. Metodologiczne ramy analizy." Studia Politologiczne 17:63-88.

Korzeniewski, Bartosz. 2010. Transformacja pamięci. Przewartościowania w pamięci przeszłości a wybrane aspekty funkcjonowania dyskursu publicznego o przeszłości w Polsce po 1989 roku. Poznan: Poznańskie Towarzystwo Przyjaciół Nauk.

Kowalczyk, Izabela (ed.). 2018. Polki. Patriotki. Rebeliantki. Warsaw: Galeria Miejska Arsenał.

Kuciel-Frydryszak, Joanna. 2018. Stużace do wszystkiego. Warsaw: Marginesy.

Kwaśniewska, Maria and Grzegorz Niziołek (eds.). 2014. Zła pamięć. Przeciw-historia w polskim teatrze i dramacie. Wroclaw: Instytut im. Jerzego Grotowskiego.

Kymlicka, Will. 2007. Multicultural odysseys: Navigating the New International Politics of Diversity. Oxford: Oxford University Press.

Leydesdorff, Selma. 2009. "Introduction to the Transaction Edition. Gender and Memory Ten Years On." Pp. vii-xvi in Gender and Memory, edited by S. Leydesdorff, L. Passerini, and P. Thompson. New Brunswick, London: Transaction Publishers.

Leydesdorff, Selma, Luisa Passerini, and Paul Thompson (eds.). 2009. Gender and Memory. New Brunswick, London: Transaction Publishers.

Lipiński, Artur. 2015. “Wartość pamięci i mnemoniczne struktury możliwości. Uwarunkowania pamięci zbiorowej w badaniach polityki kontestacji." Środkowoeuropejskie Studia Polityczne 4:133-152.

Madejska, Marta. 2018. Aleja włókniarek. Wolowiec: Czarne.

Majewska, Ewa. 2018. Kontrpubliczności ludowe i feministyczne. Wczesna "Solidarność" Czarne Protesty. Warsaw: Książka i Prasa.

Mouffe, Chantal. 2008. Polityczność. Warsaw: Wydawnictwo Krytyki Politycznej.
Naser, Nancy and Aaxel Honneth. 2003. Redistribution or recognition? A political-philosophical exchange. London, New York: Verso.

Niziołek, Grzegorz. 2016a. "Cenzura w afekcie." Teksty Drugie 4. Retrieved December 29, 2019 (http://journals.openedition. org/td/4665).

Niziołek, Grzegorz. 2016b. “Coming in. Przyczynek do badania historii homoseksualności." Teksty Drugie 6. Retrieved December 29, 2019 (http://journals.openedition.org/td/1679).

Ostrowska, Joanna. 2018. Przemilczane. Seksualna praca przymusowa w czasie II wojny światowej. Warsaw: Marginesy.

Parekh, Bhikthu. 2000. Rethinking Multiculturalism: Cultural Diversity and Political Theory. Basingstoke: Macmillan.

Penn, Shana. 2014. Sekret "Solidarności." Kobiety, które pokonaty komunizm w Polsce. Warsaw: WAB.

Pink, Sarah. 2011. “Zwiedzania miasta. Sensoryczny charakter więzi społecznych w etnograficznym procesie wytwarzania miejsca." Tematy z Szewskiej 1(5):137-148.

Putnam, Robert D. 2007. "E Pluribus Unum: Diversity and Community in the Twenty-First Century." Scandinavian Political Studies 30(2):137-174.

Ricoeur, Paul. 1973. "The hermeneutical function of distanciation." Philosophy Today 17(2):129-141.

Ricoeur, Paul. 1976. Interpretation theory: Discourse and the surplus of meaning. Fort Worth: Texas Christian University Press.

Ricoeur, Paul. 1984. Time and narrative. Chicago: University of Chicago Press.

Saryusz-Wolska, Magdalena (ed.). 2009. Pamięć zbiorowa i kulturowa. Wspótczesna perspektywa niemiecka. Cracow: Universitas.

Saryusz-Wolska, Magdalena and Robert Traba. 2014. "Przeciw-pamięć." Pp. 396-403 in Modi memorandi. Leksykon kultury pamięci, edited by M. Saryusz-Wolska and R. Traba. Warsaw: Wydawnictwo Naukowe Scholar.

Schmidt, Carl. 2000. Teologia polityczna i inne pisma. Cracow: Znak.

Sieracka, Joanna. 2015. “Postfeministyczne próby odzyskania „kobiecego doświadczenia” jako odpowiedź na trzeciofalowy 
kryzys zwrotu doświadczeniowego." Pp. 76-83 in Tematy modne $w$ humanistyce studia interdyscyplinarne, edited by Ł. Grajewski et al. Torun: „ProLog.”

Stomma, Ludwik. 2002. Antropologia kultury wsi polskiej XIX wieku oraz wybrane eseje. Lodz: Piotr Dopierała.

Szacka, Barbara. 2006. Czas przeszły - pamięć - mit. Warsaw: Wydawnictwo ISP PAN.

Szlaki kobiet. Przewodniczka po Polsce emancypantek. 2015. Edited by E. Furgał. Kraków: Fundacja Przestrzeń Kobiet.

Taylor, Charles. 1993. "Shared and Divergent Values." Pp. 155186 in Reconciling the Solitudes, Essays on Canadian Federalism and Nationalism, edited by Ch. Taylor and G. Laforest. Montreal: McGill-Queen's University Press.

Urbanik-Kopeć, Alicja. 2018. Anioł w domu, mrówka w fabryce. Warsaw: Krytyka Polityczna.

Vandenbroek, Angela Kristin. 2011. "Agency and Practice Theory." Pp. 481-487 in 21st century anthropology: a reference hand- book, vol. I, edited by H. J. Brix. Thousand Oaks, CA: SAGE Publications.

von Rohrscheidt, Armin Mikos. 2011. "Klasyczne i nowoczesne formy zorganizowanego zwiedzania miasta." Pp. 139-183 in Obcy w Poznaniu. Historyczna metropolia jako ośrodek turystyki kulturowej, edited by A. M. von Rohrscheidt. Poznan: Wydawnictwo Kultour.pl.

Wodak, Ruth and Veronika Keller (eds.). 2008. Handbook of communication in the public sphere. Berlin: Mouton de Gruyter.

Vuković, Desna. 2007. “Polityka przestrzeni." Maszyna interpretacyjna 4(37):39-43.

Wawrzyński, Patryk. 2014. "Sharing the Past: Specialized Institutions as an instrument of Politics of Memory in the 21st Century." Pp. 209-228 in Society and Nation in Transnational Processes in Europe, edited by R. Schattkowsky and M. Reznik. Newcastle: Cambridge Scholar Publishing.

Waxman, Zoe. 2017. Women in the Holocaust. A Feminist History. Oxford: Oxford University Press.

\section{Citation}

Kuźma, Inga B. and Edyta Pietrzak. 2020. "Gendering Memory: Intersectional Aspects of the Polish Politics of Memory." Przeglad Socjologii Jakościowej 16(1):102-118. Retrieved Month, Year (www.przegladsocjologiijakosciowej.org). DOI: http://dx.doi. org/10.18778/1733-8069.16.1.07

\section{Gendering Memory: intersekcjonalne aspekty polskiej polityki pamięci}

Abstrakt: Artykuł poświęcony jest procesowi zarządzania pamięcią w szczególnym aspekcie - ze względu na problematykę gender (nurt gendering memory), co zdaniem autorek tekstu jest kontrapunktem wobec tendencji upolitycznienia pamięci, które mają miejsce w Polsce. Autorki ilustrują tę problematykę lokalnym przypadkiem wiążącym kategorię gender z miejską sferą publiczną, a mianowicie odwołują się działań Fundacji Łódzki Szlaku Kobiet (https://www.facebook.com/ŁódźkiSzlakKobiet - jest to kobieca oddolna inicjatywa dotycząca zarazem płci społeczno-kulturowej, jak i przeszłości i pamięci miasta. Artykuł składa się z trzech głównych części odnoszących się do: 1. funkcjonowania pamięci w miejskiej sferze publicznej jako formy dialogu (antropologia hemerneutyczno-interpretacyjna w oparciu o teorie Jurgena Habermasa i Seyli Benhabiba), 2. procesu gendering memory (odzwierciedlającego pluralizację pamięci), 3. działań Fundacji Łódzki Szlak Kobiet (gdzie miasto jawi się jako zróżnicowany krajobraz pamięci). Artykuł dotyczy napięcia obserwowanego między polityką pamięci - praktyką polityczną - alternatywnymi pamięciami wynikającymi z idei wielości i polifonii, w tym obecności głosu kobiet. Autorki artykułu podnoszą kwestię genderyzacji pamięci w kontekście pytań, w jaki sposób rozwija się pluralizm pamięci zbiorowej i toczy się dywersyfikacja sfery publicznej jako rezultat oddziaływania dyskursów pamięci alternatywnej, w tym pamięci skoncentrowanej na płci.

Słowa kluczowe: emancypacja pamięci, herstory, polityka historyczna, sfera prywatna, sfera publiczna, pamięć alternatywna 